\title{
GROUNDWATER VULNERABILITY GIS MODELS IN THE CARPATHIAN MOUNTAINS UNDER CLIMATE AND LAND COVER CHANGES
}

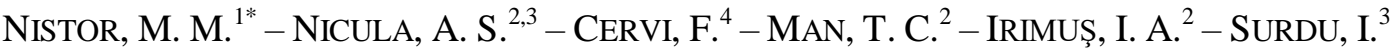 \\ ${ }^{1}$ School of Civil and Environmental Engineering, Nanyang Technological University, Singapore \\ ${ }^{2}$ Faculty of Geography, University of Babeş-Bolyai, Cluj-Napoca, Romania \\ ${ }^{3}$ Centre of Mountain Economy of the National Institute for Economic Research "Costin C. \\ Kiritgescu”, Romanian Academy, Bucharest, Romania \\ ${ }^{4}$ Department of Civil, Chemical, Environmental and Materials Engineering, University of \\ Bologna, Bologna, Italy \\ *Corresponding author \\ e-mail: renddel@yahoo.com
}

(Received $16^{\text {th }}$ May 2018; accepted $31^{\text {st }}$ Jul 2018)

\begin{abstract}
Water resources are facing nowadays with two main problems: climate change and land cover variation. Their influences on environment and water resources have been evidenced worldwide. In this work, we have applied a complex methodology based on Geographical Information System (GIS) to combine the spatial information of several parameters that allow to obtain the groundwater vulnerability under climate and land cover modifications. The spatial analysis performed in this paper includes the aquifers, water availability, load pollution index, and infiltration map raster grids data of Carpathian Mountains area, from Central Europe. The analysis presented in this study follow three periods, which include 30 years climate data models of 1961-1990 (1990s), 2011-2040 (2020s), and 2041-2070 (2050s). Land cover projections forecast future changes in artificial areas, agriculture areas, and forest areas for 2020 s and 2050s. For both periods (2020s and 2050s), the very low vulnerability class area is reduced while the high class appears on a large area. The worst scenario is forecasted for 2050s (high vulnerability class increase up to $2.41 \%$ of the whole study area) and is mainly due to agriculture. These findings evidence the negative impact of land cover and climate changes on the groundwater resources in the Carpathians Mountains area. The original maps carried out in this work together with the concise methodology integrated in GIS may be a useful tool for the water resources management and future strategies plans of this region.
\end{abstract}

Keywords: climatic models, aquifers, pollution load index, infiltration map, water availability, spatial analysis

Abbreviations: GIS - Geographical Information Systems; $\mathrm{K}_{\mathrm{c}}$ - crop coefficients; $\mathrm{ET}_{\mathrm{c}}-$ crop evapotranspiration; $\mathrm{ET}_{0}$ - potential evapotranspiration; AETc - actual crop evapotranspiration; PLI pollution load index; PIC - potential infiltration coefficient; DEM - digital elevation model; asl - above sea level; Dfb - fully humid climate and warm summers; Dfc - fully humid precipitation conditions and cool summers; AOGCM - Atmosphere Ocean Global Climate Model; CMIP5 - Coupled Model Intercomparison Project phase 5; CanESM2 - Canadian Earth System Model 2; CCSM4 - Community Climate System Model version 4; INM-CM4 - Institute of Numerical Mathematics Climate Model version 4; ACCESS1.0 - Australian Community Climate and Earth System Simulator; HadGEM2-ES Hadley Centre Global Environment Model version 2; MRI-CGCM3 - Meteorological Research Institute Coupled Global Climate Model version 3; IPSL-CM5A-MR Institut Pierre Simon Laplace Climate Model 5A Medium resolution; CNRM-CM5 - Centre National de Recherches Météorologiques Climate Model version 5; MIROC-ESM - Model for Interdisciplinary Research on Climate Earth System Models; MIROC5 - Model for Interdisciplinary Research on Climate version 5; CSIRO Mk 3.6 - Commonwealth Scientific and Industrial Research Organisation model version 3.6; CESM1-CAM5 - Community Earth System Model version 1 Community Atmosphere Model version 5; MPI-ESM-LR - Max-Planck-Institut 
für Meteorologie Earth System Model on Low Resolution; GFDL-CM3 - Geophysical Fluid Dynamics Laboratory Climate Model version 3; GISS-E2R - Goddard Institute for Space Studies ModelE 2 Russell ocean model

\section{Introduction}

Groundwater represents the most important freshwater resources for human purposes. Several authors highlighted the influence of climate and land cover changes occurred in the last decades on groundwater, both in term of quality and quantity. In particular, severe impact took place in Mediterranean countries and South-central Europe. Galleani et al. (2011), Čenčur Curk et al. (2014), Nistor et al. (2015) signalled the negative effect of climate change on groundwater. Kløve et al. (2014) illustrated the negative impact of climate changes on the related ecosystems. The recent climate warming (Haeberli et al., 1999) indicates negative effects on the natural and seminatural places (Nistor and Mîndrescu, 2017). Due to climate change, in the next decades the mean annual temperatures are expected to increase (IPCC, 2001) and several models indicate rise of temperature during the $21^{\text {st }}$ century (IPCC Assessment Report 5, 2013; Stocks et al., 1998; Shaver et al., 2000; Stavig et al., 2005; The Canadian Centre for Climate Modelling, 2014). Aguilera and Murillo (2009), Jiménez Cisneros et al. (2014), Kløve et al. (2014) signalled several problems that appeared in the biodiversity and surface waters depletion related to climate change. In the temperate zone of South Europe and Turkey, the precipitation amount will reduce (Čenčur Curk et al., 2014; Cheval et al., 2017; Nistor and Mîndrescu, 2017). The dynamics of the land cover and the human activities at continental scale are going to affect the water resources, which are sensitive to urbanization, agricultural lands' exploitations, and improper forest management, e.g. deforestation, chaotic building in the forest proximity. With respect to the decrease of precipitation, the groundwater recharge is influenced from quantity point of view (Nistor et al., 2015). On other hand, the possibility of rainfall intensity increase will affect directly the infiltration rate on short-term period.

The temperature pattern together with the land cover contribute at the evapotranspiration processes taking place on the recharge areas. In the central and eastern Europe, the Carpathian Mountains area represents a precious reservoir of water resources, especially for many establishments of the region, but also for the large cities located out of the Carpathians, such as Bucharest and Cluj-Napoca. Moreover, the studies show that the crop evapotranspiration (ETc) increase from the past period to 2050s (Nistor et al., 2016) and the deforestation of the several sectors in the Carpathian Mountain area could damage the regime of watershed basins.

The goal of this work is to define the most sensitive layers for groundwater at climate change and cover modifications on long-term and to generate the spatial analysis for groundwater vulnerability in the Carpathian Mountains area. We used high-resolution climate models of mean annual air temperature, mean annual precipitation, and annual ET0 for 1990s, 2020s, and 2050s periods and the CORINE land cover dated from 2010 (World Land Cover 30m) and three projections for 2050s. In addition, the aquifers layer of the study area and the digital elevation model (DEM) were integrated in the methodology of the paper. Thus, the determination of groundwater vulnerability in the study area is based on a spatial analysis by weights using ArcGIS environment.

Following the method of Nistor et al. (2015), tested in a small area of the Beliș district from Apuseni Mountains, our approach and obtained results are reliable at large scale, being important instruments for the panning of this large mountain area. 


\section{Materials and methods}

\section{Study area}

The Carpathian Mountains area extends from $44^{\circ} 28^{\prime}$ to $49^{\circ} 51^{\prime} \mathrm{N}$ and from $18^{\circ} 00^{\prime}$ to $26^{\circ} 46^{\prime} \mathrm{E}$ (Fig. 1). The geographical position in the central part of Europe and the large natural sectors of these mountains makes the Carpathians to be the most important ecosystem from this side of the continent (Nistor et al., 2016). Here, we simply defined the Western Carpathians in the northwestern side of the study area, the eastern Carpathians mainly in Romania and Ukraine, and Southern Carparthians. In addition, we highlighted the Curvatures Carpathians and Apuseni Mountains as two units used in the paper for descriptions and toponymy points of view. Moreover, the analysed area represents a significant source of drinking water with valuable aquifers (e.g. highly productivity fissured aquifers, highly productive porous aquifers). In base of the geomorphology present in the region, the orography of the Carpathians is much diversified and could be reflected in the runoff pattern and infiltration processes. The elevations ranges mainly from $300 \mathrm{~m}$ in depression and valleys to $2642 \mathrm{~m}$ in Gerlachovský Peak from Slovakia. The geology of the territory is complex and could be easier reflected into the aquifers composition. The main geological formations are represented by gneisses, mica schists and amphibolites in the Southern Carpathians and by marlstones, limestones, clays, marls, sandstones and sands in the Curvatures Carpathians and Eastern Carpathians. Pyroclastic rocks, volcanic rocks, marlstones, dolomitic limestones, gravels and clays are presented in the Western Carpathians and Apuseni Mountains. Figure Al in the Appendix (BGR and UNESCO, 2013) shows the geological formations of the Carpathian Mountains area. In base of the BGR and UNESCO (2013) map, the aquifers types are divided in six categories of productivity: highly productive fissured aquifers, highly productive porous aquifers, low and moderately productive fissured aquifers, low and moderately productive porous aquifers, locally aquiferous rocks - porous or fissured, practically non-aquiferous porous or fissured. Table 1 indicates the aquifers types in the Carpathian region area.

The climate of the study area has oceanic influences in the West and North-West, Baltic influence in the North and Mediterranean influence in the South-West. According to the Köppen-Geiger climate classification, the Carpathian Mountains area has Dfb climate in the main part pf territory, with fully humid climate and warm summers (Kottek et al., 2006). In the eastern sectors of the Romanian and Ukrainian Carpathians, in the central parts of the Slovakian Carpathians and in South Poland, the study area have a Dfc climate type, characterized by fully humid precipitation conditions and cool summers (Kottek et al., 2006). During the 1990s, the mean annual temperature in the study area ranged from -3.1 to $11.4{ }^{\circ} \mathrm{C}$ (Fig. 2). The precipitation pattern shows values between $546 \mathrm{~mm}$ to $1695 \mathrm{~mm}^{-1} \mathrm{ear}^{-1}$ during 1990s (Fig. 2b). The annual ET0 in the Carpathian Mountains area ranged from $279 \mathrm{~mm}$ up to $548 \mathrm{~mm}$ during 1990s (Fig. 2c).

The land cover of the Carpathian Mountains area is composed at high elevations (over $1000 \mathrm{~m}$ asl) by forest and pasture (coniferous, mixed and broad-leaved forests), the valleys and depressions are covered by agricultural cultivated lands, villages and also cities. The cities and rural localities compose the artificial areas in the Carpathian mountain region. For groundwater vulnerability determination, the land cover has a quantitative role with respect to the evapotranspiration and water availability and a qualitatively role due to the phosphorous and load pollution present in each type of land cover. 


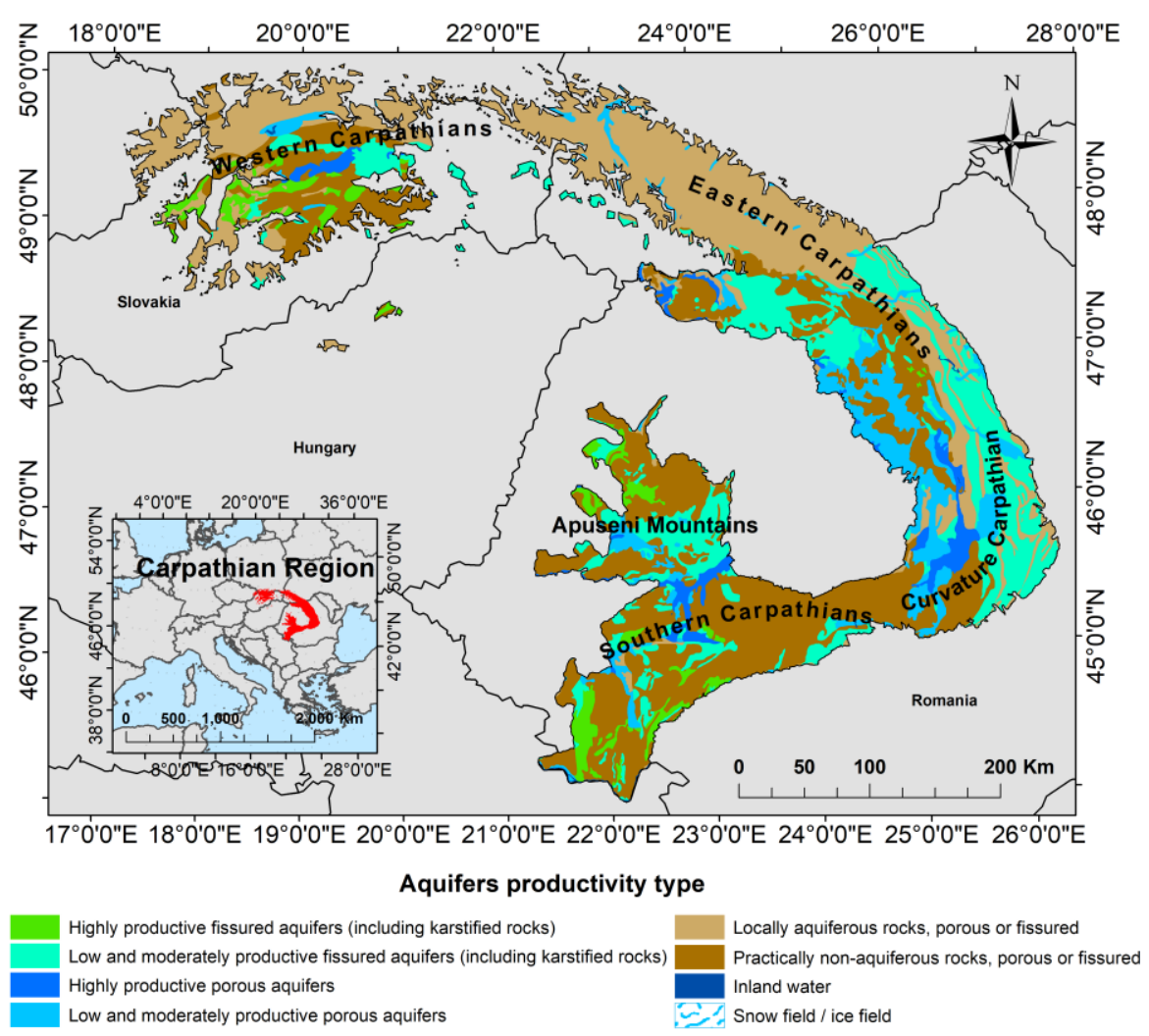

Figure 1. Location of the Carpathian Mountains region on the South-central map and the main aquifers productivity type in the region
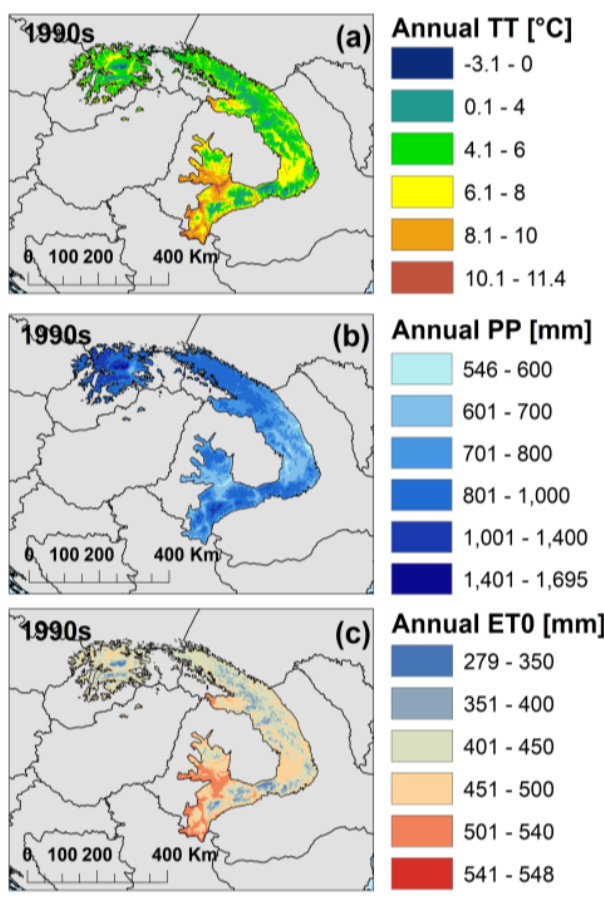

Figure 2. Spatial distribution of temperature, precipitation, and ETO in the Carpathian Mountains region. (a) The average of mean annual air temperature between 1961 and 1990 (1990s). (b) The average of mean annual precipitation between 1961 and 1990 (1990s). (c) The average of mean annual precipitation between 2011 and 2040 (2020s) 
Table 1. Summary of the climate models used in the application of groundwater vulnerability assessment for the Carpathian region. (Sources: Scherrer, 2011; Watanabe et al, 2011; Hamann et al., 2013; IPCC Assessment Report 5, 2013; Knutti et al., 2013; Ohgaito et al., 2013; Wang et al., 2016)

\begin{tabular}{c|c|c}
\hline \multicolumn{2}{c}{ CMIP5 multi-model dataset which compose the ensemble average of 15 AOGCMs } \\
\hline CanESM2 & CCSM4 & INM-CM4 \\
ACCESS1.0 & HadGEM2-ES & MRI-CGCM3 \\
IPSL-CM5A-MR & CNRM-CM5 & MIROC-ESM \\
MIROC5 & CSIRO Mk 3.6 & CESM1-CAM5 \\
MPI-ESM-LR & GFDL-CM3 & GISS-E2R \\
\hline
\end{tabular}

\section{Climate data}

High spatial-resolution data $\left(1 \mathrm{~km}^{2}\right)$ in three periods (past - 1961-1990, present 2011-2040, and future - 2041-2070) of monthly mean precipitation, monthly ET0, and annual ET0 were used in this study to carry out the water availability. The climate models of temperature and precipitation were developed and validated for whole Europe (Hamann et al., 2013).

Regarding the source of base dataset and type of meteorological stations, as well as the number of stations included in the normal period (1961-1990), we would like to mention that the data used in this paper is online available (http://www.cru.uea.ac.uk/) and it belong to the CRU TS 2.1 project (Mitchell and Jones, 2005). The dataset contains mean monthly precipitation and mean, minimum, and maximum monthly temperature and it were quality controlled and checked for inhomogeneities (New et al., 1998). For Europe, gridded climatological data, at finer spatial resolution of $0.5^{\circ}$ lat $\mathrm{X}$ $0.5^{\circ}$ long, were constructed using surface observations from about 1644 stations for temperature (344 for mean monthly temperature, 647 for minimum monthly temperature, and 653 for maximum monthly temperature). For the precipitation gridded data were used about 1333 meteorological stations.

The models performed by Hamann et al. (2013) were done in base of Parameter Regression of Independent Slopes Model (PRISM) for precipitation and ANUSplin for temperature, considering the Representative Concentration Pathway (RCP) of 4.5 for emission, which means a moderate climate changes projection, based on a globally predicts of $+1.4{ }^{\circ} \mathrm{C}( \pm 0.5)$. The ANUSplin interpolation procedure is in line with Mitchell and Jones (2005). In the climate models creation ClimateEU v4.63 software was used, available on the website (http://tinyurl.com/ClimateEU). The base-dataset is in principle described by Wang et al. (2016) in their study about historical and future climate in North America (https://sites.ualberta.ca/ ahamann/publications/pdfs/Wang_et_al_2016.pdf).

The climate models represent an ensemble average of 15 AOGCMs, consider the CMIP5 multi-model dataset accordingly IPCC Assessment Report 5 (2013). To represent the main clusters of similar AOGCMs, the individual models were selected (Knutti et al., 2013). The chosen of these models was based on the high validation statistics in the CMIP3 equivalents (Scherrer, 2011). The models which compose the ensemble average of AOGCMs are reported in the Table 1.

The bilinear interpolation was used to correct the artefacts in the AOGCM grid cells, for the adjacent areas. A Change Factor (CF) method for the GCM results have been 
applied instead the bias correction. The methodology of the climate models is in line with Daly (2006). Moreover, the models were validated and described by Hamann and Wang (2005), Mbogga et al. (2009), Wang et al. (2016), Dezsi et al. (2018). At the continental and regional scales, the evapotranspiration studies were completed by Nistor (2018a, b) and Nistor et al. (2018).

\section{Aquifers data}

The Carpathian Mountains area has a diversified geology, composed by clays, conglomerates, metamorphic, limestones, carbonated, and plutonic rocks (Fig. Al). Accordingly to the geological compositions, the International Hydrogeological Map of Europe (IHME), dating from 2013 at 1:1,500,000 scale (BGR and UNESCO, 2013) reported six types of aquifer's productivity (Fig. 1). In base of the productivity of aquifers, the vulnerability factor for each aquifer was assigned into the GIS database (Table 2) and further at spatial scale of Carpathian Mountains region (Fig. 3). For each media that compose the aquifer, the potential infiltration coefficient (PIC) was assigned accordingly to the hydrogeological specific literature (Civita, 2005). The importance of infiltration coefficients for groundwater highlights the aquifers sensitivity in term of quality (Čenčur Curk et al., 2014). Figure A2 in the Appendix shows the PIC spatial distribution in the Carpathian Mountains area.

Table 2. Aquifers productivity in Carpathian Mountains region. (Source: IHME, 2013; Čenčur Curk et al, 2014)

\begin{tabular}{c|c}
\hline Aquifers type & Vulnerability factor \\
\hline Highly productive fissured aquifers (including karstified rocks) & 0.8 \\
Low and moderately productive fissured aquifers (including karstified rocks) & 0.4 \\
Highly productive porous aquifers & 0.7 \\
Low and moderately productive porous aquifers & 0.3 \\
Locally aquiferous rocks, porous or fissured & 0.1 \\
Practically non-aquiferous rocks, porous or fissured & 0.05 \\
Snow field/ice field & 0 \\
\hline
\end{tabular}

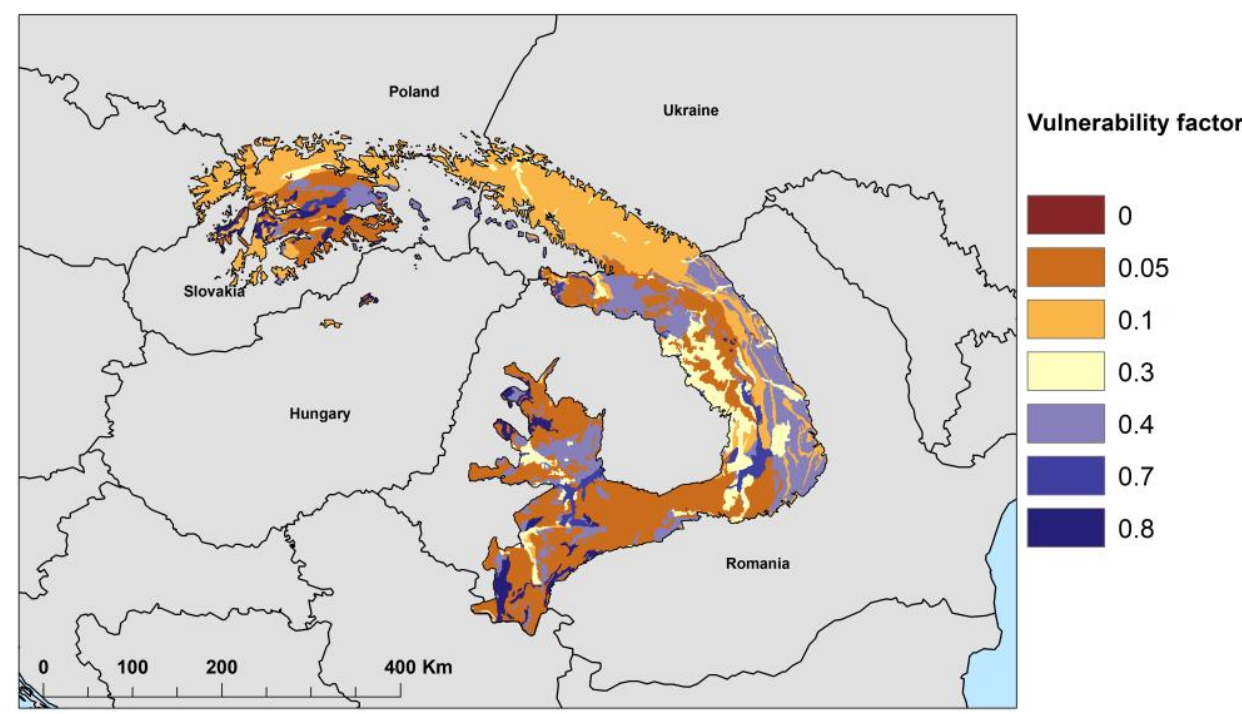

Figure 3. Vulnerability factor distribution at spatial scale of the Carpathian Mountains region 


\section{Terrain data and infiltration map}

The infiltration process is mainly controlled by the terrain configuration and lithology. In base of the Nistor et al. (2015) approach, the infiltration map is calculated as the ratio between PIC and slope angle. Thus, the digital elevation model (DEM) of the Carpathians region have been used to generate the slope angle and from the geological map it was processed the PIC. This reasoning considers that where the PIC is higher and the slope angle is lower, the infiltration values will be higher. The calculations were performed in ArcGIS software using normalized values ( 0 to 1$)$ of the PIC and slope angle raster grid data. Figure 4 depicts the infiltration map of the Carpathian Mountains area used in the groundwater vulnerability mapping.

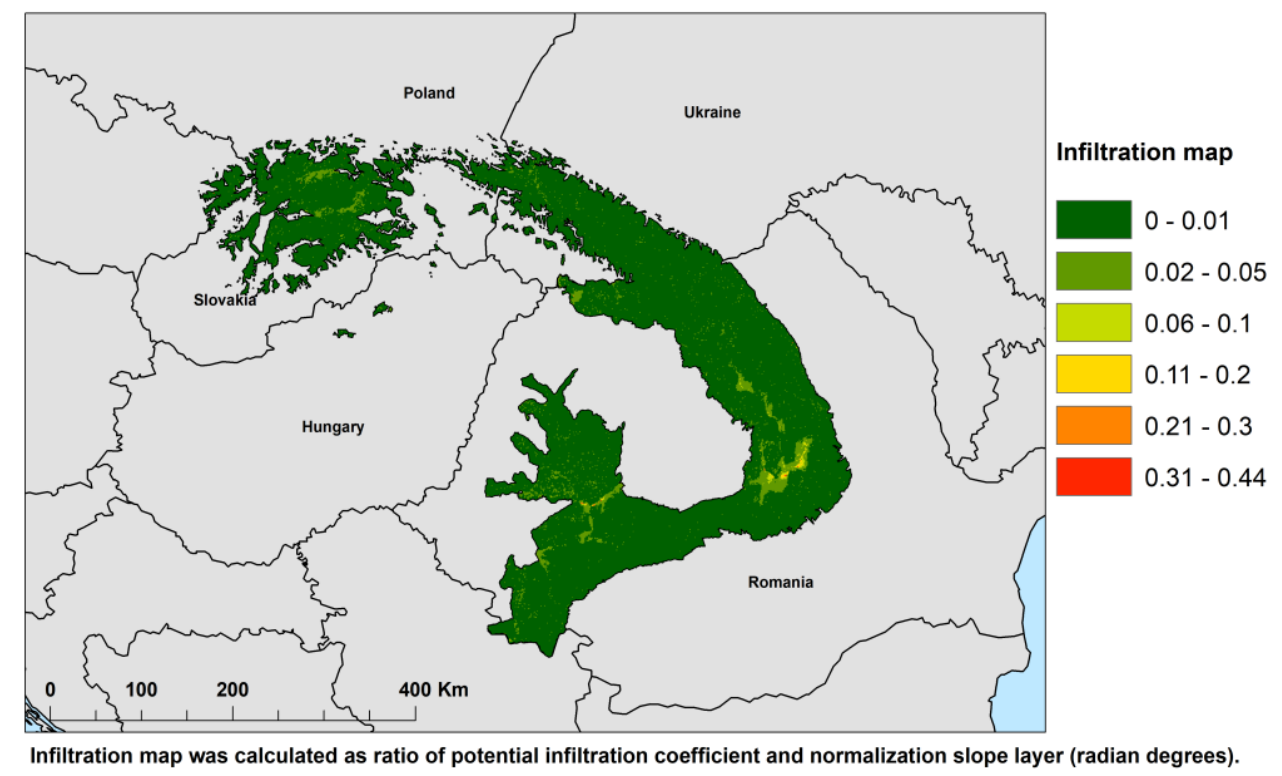

Figure 4. Infiltration map of the Carpathian Mountains region

\section{Land cover data}

The vegetation layer, bare soil, water bodies, and artificial areas over Carpathian Mountains area were collected from the World Land Cover database elaborated by China in collaboration with the United Nations. This land cover is $30 \times 30 \mathrm{~m}$ in spatial resolution and cover entire study area indicating 10 classes of cover type. The future projections of the land cover were done accordingly to Nistor et al. (2015) only for the artificial, agricultural, and forest areas. All transformations have been processed on the vector layer of and cover, applying a linear buffer to the vector feature of artificial areas by $23 \mathrm{~m}$, to agriculture by $41 \mathrm{~m}$, and to forest by $80 \mathrm{~m}$. Thus, the resulted surfaces were clipped and integrated in the original land cover vector layer for present and future (Fig. A3). Table 3 reports the values of pollution load index (PLI) used in the present study. The resolution of the PLI at spatial scale (Fig. 5) were set at $1 \mathrm{~km}^{2}$, to be in line with the climatological data.

\section{Potential evapotranspiration (ET0)}

Thornthwaite (1948) method (Eq. 1) was adopted for the long-term calculations of monthly ET0 during the three set time periods: 1961-1990 (1990s), 2011-2040 (2020s), 
and 2041-2070 (2050s). Even if old, this approach is still used in the regional studies of climate, hydrology, and agriculture (Zhao et al., 2013). The monthly and annual ET0 and water availability have been computed for whole Europe by Dezsi et al. (2018) and the gridded data are available through open access web site (https://doi.org/10.5281/zenodo.1044306). In base of monthly ET0 we have computed the annual ET0 and further annual ETc and AETc raster maps.

$$
\mathrm{ET}_{0}=16\left(\frac{10 \mathrm{~T}_{\mathrm{i}}}{\mathrm{I}}\right)^{\alpha}
$$

where:

$\mathrm{ET}_{0}-$ monthly potential evapotranspiration $[\mathrm{mm}]$

$\mathrm{T}_{\mathrm{i}}-$ average monthly temperature $\left[{ }^{\circ} \mathrm{C}\right], \mathrm{ET}_{0}=0$ if mean temperature $<0$

I - heat index (Eq. 2)

$\alpha$ - complex function of heat index (Eq. 3)

$$
\mathrm{I}=\sum_{\mathrm{i}=1}^{12}\left(\frac{\mathrm{T}_{\mathrm{i}}}{5}\right)^{1.514}
$$

where:

$\mathrm{T}_{\mathrm{i}}$ - monthly air temperature

$$
\alpha=6.75 \times 10^{-7} \mathrm{I}^{3}-7.71 \times 10^{-5} \mathrm{I}^{2}+1.7912 \times 10^{-2} \mathrm{I}+0.49239
$$

where:

I - annual heat index

Table 3. Corine Land Cover classes and relative pollution load index applied the Carpathian region. (Source: Wochna, 2011; Čenčur Curk et al., 2014; Nistor et al., 2015)

\begin{tabular}{c|c|c|c}
\hline CLC code 2012 & CLC description & Pollution load index & Normalized values \\
\hline 133 & Artificial surface & 7 & 0.35 \\
211 & Non-irrigated arable land & 12 & 0.80 \\
313 & Forest & 2.8 & 0.18 \\
321 & Grasslands & 2.5 & 0.16 \\
324 & Shrubland & 2.6 & 0.17 \\
332 & Bareland & 5 & 0.33 \\
335 & Permanent snow and ice & 0.1 & 0.007 \\
411 & Wetland & 2.3 & 0.15 \\
512 & Water bodies & 3 & 0.20 \\
\hline
\end{tabular}

\section{ETc, AETc, and water availability}

In base of crop coefficients $(\mathrm{Kc})$ assigned to each land cover type we have carried out the ETc. Allen et al. (1998) present the standard Kc for various types of crops. Moreover, Grimmond and Oke (1999) calculated the Kc in the urban areas indicating the specific Kc for several cities in the United States. In South Europe, Nistor and Porumb-Ghiurco (2015) set a methodology for the ETc mapping at spatial scale. 

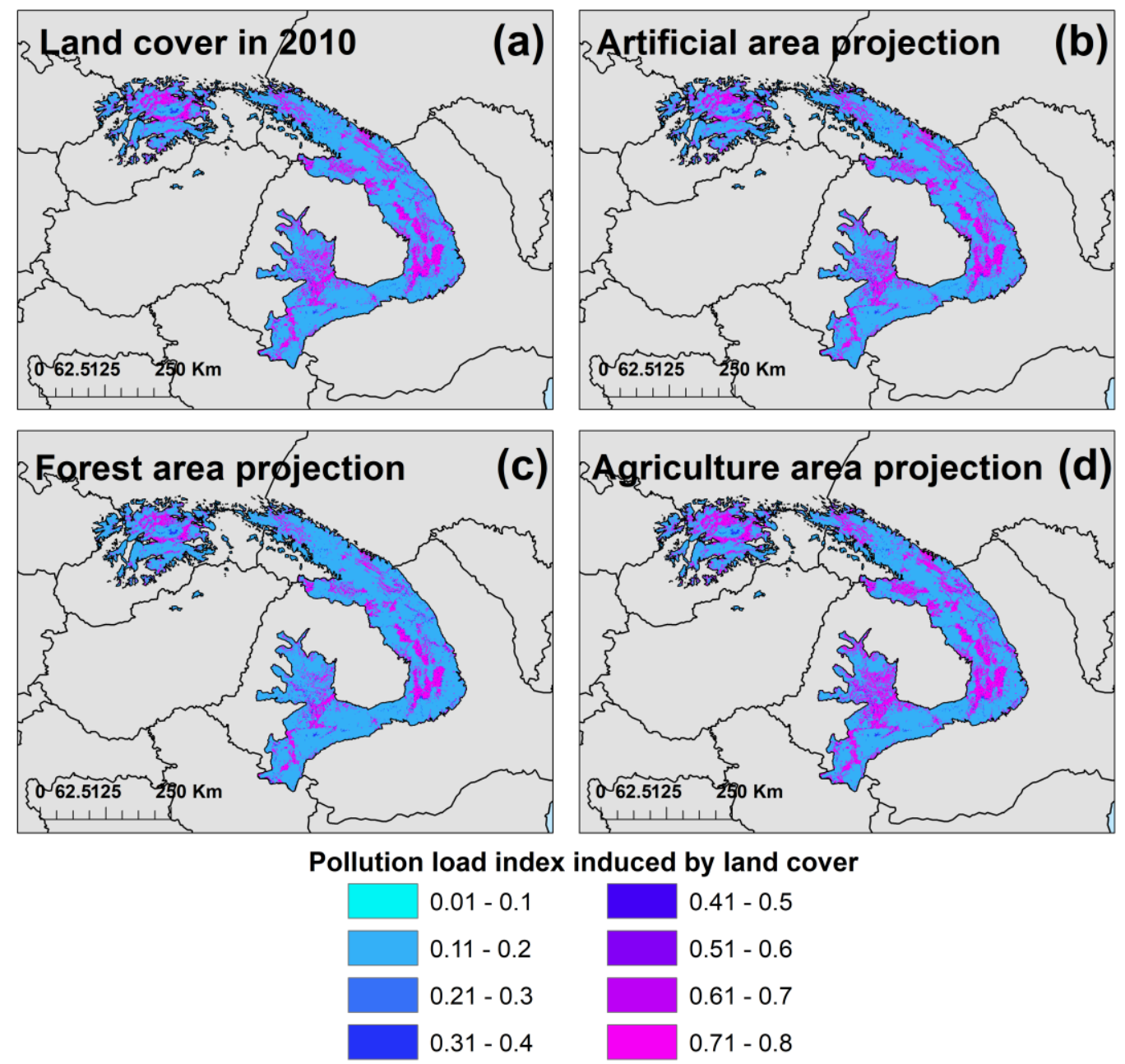

Figure 5. Pollution load index calculated in base of land cover in the Carpathian Mountains region. (a) Pollution load index pattern related to land cover 2010. (b) Pollution load index pattern related to artificial area projection. (c) Pollution load index pattern related to forest area projection. (d) Pollution load index pattern related to agricultural area projection

The calculation of ETc is the product of the ET0 and Kc $(E q .4)$. We prefer to incorporate the land cover in the evapotranspiration calculation because the aquifers recharge is in base of effective precipitations, which are not included in the water demand for crops. In this work, we have used the standard annual Kc values (Nistor and Mîndrescu, 2017) together with the annual ET0 to determinate the annual ETc for the past, present, and future. The annual $\mathrm{Kc}$ values, for the land cover classes related to Carpathian Mountains are presented in the Table 4.

Budyko approach (1974) was adopted to carry out the AETc calculation. This method is often used in the hydrology and related studies which required the water balance determination (Gerrits et al., 2009).

$$
\text { Annual ETc }[\mathrm{mm}]=\text { annual ET0 }[\mathrm{mm}] \times \text { annual } \mathrm{Kc}[\mathrm{mm}]
$$

From the difference between precipitation and AETc, we have found the water availability. Budyko (1974) formula is expressed in Equation 5. The water availability 
(Eq. 7) for 1990s, 2020s, and 2050s was subtracted from the annual AETc and annual precipitation. All raster grids operations were performed in ArcGIS environment.

$$
\frac{\mathrm{AETc}}{\mathrm{PP}}=\left[\left(\varphi \tan \frac{1}{\varphi}\right)\left(1-\exp ^{-\varphi}\right)\right]^{0.5}
$$

where:

AETc - actual land cover evapotranspiration [mm]

$\mathrm{PP}$ - total annual precipitation [mm]

$\Phi$ - aridity index (Eq. O)

$$
\varphi=\frac{\mathrm{ETc}}{\mathrm{PP}}
$$

Effective precipitation $[\mathrm{mm}]=$ annual precipitation[mm] - annual AETc[mm] (Eq.7)

Table 4. Corine Land Cover classes and appropriate annual Kc used for ETc in Carpathian Mountains region. (Source: From Allen et al., 1998; Nistor and Mîndrescu, 2017)

\begin{tabular}{c|c|c|c|c|c|c}
\hline \multicolumn{3}{c|}{ Corine land cover } & \multicolumn{5}{|c}{ Kc annual } \\
\hline CLC code 2012 & CLC description & Kc & Ks & Ku & Kw & Kclc \\
\hline 133 & Artificial surface & - & - & 0.26 & - & 0.26 \\
211 & Non-irrigated arable land & 1.14 & - & - & - & 1.14 \\
313 & Forest & 1.35 & - & - & - & 1.35 \\
321 & Grasslands & 0.95 & - & - & - & 0.95 \\
324 & Shrubland & 0.9 & - & - & - & 0.9 \\
332 & Bareland & - & 0.2 & - & - & 0.2 \\
335 & Permanent snow and ice & - & - & - & 0.51 & 0.51 \\
411 & Wetland & - & - & - & 0.45 & 0.45 \\
512 & Water bodies & - & - & - & 0.64 & 0.64 \\
\hline
\end{tabular}

$\mathrm{Kc}$ - crop coefficient for plants, $\mathrm{Ks}$ - evaporation coefficient for bare soils, $\mathrm{Ku}$ - crop coefficient for urban areas, $\mathrm{Kw}$ - evaporation coefficient for open water, Kclc - crop coefficient for land cover

\section{Groundwater vulnerability assessment using Spatial Analyst Tools}

The groundwater vulnerability mapping was determinate by multi-layers analysis using Spatial Analyst Tools from ArcGIS. The method adopted here is based on the methodology applied by Nistor et al. (2015). In European regions, Čenčur Curk et al. (2014) performed the groundwater vulnerability in the South East Europe using weights. In the works of Stempvoort et al. (1993), Daly et al. (2002) and Dixon (2005), the appropriate weights for each layer were found.

We consider that the water availability represents one of the most important layers related to the water recharge quantity, which is driven by climate. Secondly, the land cover variability and implication for PLI and ecosystems play also an important role of the groundwater quality. Due to these reasons, we agree that water availability and ecosystems may have the same weights of $30 \%$. For the aquifers vulnerability factor 
and infiltration map were set the equal weights of $20 \%$. All layers were pondered using weights like in Equation 8. These weights represent the relative importance of the parameter in the group. The water availability and ecosystems have a balancing factor that shows the relative importance to the maximal deviations of the respective layer and its limitation to substitute another layer.

All layers were normalized under the standard method between 0 and 1. Final vulnerability map was divided in classes as follow: $0-0.2$ for very low, $0.21-0.4$ for low, $0.41-0.6$ for medium, $0.61-0.8$ for high, and $0.81-1$ for very high. The groundwater vulnerability map was divided in four classes of vulnerability: very low, low, medium, and high.

$$
\mathrm{GWV}=(1-\mathrm{WA})^{1.5} \mathrm{X} 0.3+\mathrm{AV} \times 0.2+\mathrm{IM} \times 0.2+\mathrm{ES}^{1.5} \text { X } 0.3
$$

where:

GW V = Groundwater Vulnerability

$\mathrm{WA}=$ Water Availability

$\mathrm{AV}=$ Aquifer Vulnerability

$\mathrm{IM}=$ Infiltration Map

$\mathrm{ES}=$ Ecosystem Services

\section{Results and discussion}

The climate change in Europe and in the Carpathian Mountains area indicates significant variation in the mean air temperature and evapotranspiration values for 2020s and 2050s, but also slightly modifications in the precipitation extremes. In base of the climate models observations, the mean annual temperature is expected to increase from -0.8 to $13.5{ }^{\circ} \mathrm{C}$ during the 2020s (Fig. 6a) in the Carpathian Mountains area. The future projections indicate values of the mean air temperature from 0.2 to $14.4{ }^{\circ} \mathrm{C}$ during the 2050s period (Fig. 6b) in the study area. The precipitation pattern shows values between $460 \mathrm{~mm}$ and $1667 \mathrm{~mm}$ year-1 for the 2020s (Fig. 6c) and between 478 $\mathrm{mm}$ to $1730 \mathrm{~mm} \mathrm{year}^{-1}$ for 2050s (Fig. 6d). The annual ET0 in the Carpathian Mountains area is expected to range from $312 \mathrm{~mm}$ to $674 \mathrm{~mm}$ during 2020s and from $327 \mathrm{~mm}$ to $713 \mathrm{~mm}$ during 2050s (Fig. $6 e$ and $f$ ).

Climate change effects on the Carpathian Mountains are reflected into the annual ETc. During 1990s, the annual ETc ranges $56 \mathrm{~mm}$ to $740 \mathrm{~mm}$ while in the future periods the ETc is expected to increase up to $910 \mathrm{~mm}(2020 \mathrm{~s})$, respective $963 \mathrm{~mm}$ (2050s). Figure A4 depicts the spatial variation of annual ETc in the study area, highlighting the high values (over $700 \mathrm{~mm}$ ) in the Apuseni ad Eastern Carpathians, especially during the 2020 s and 2050s periods. The large area with high values is represented by the forest projection scenario (Fig. A3d) while in the artificial and agricultural scenarios for 2050 s the ETc pattern do not differ too much (Fig. A3c and $d$ ).

The implication of the annual ETc (Fig. A4) in the groundwater vulnerability is reflected through AETc and water availability. Thus, the annual AETc varies in the past period from $55 \mathrm{~mm}$ to $525 \mathrm{~mm}$ showing the maximum values in the Western Carpathians. During 2020s period, the annual AETc ranges from $63 \mathrm{~mm}$ to $575 \mathrm{~mm}$ indicating high values (over $500 \mathrm{~mm}$ ) in the Western and Southern Carpathians. For the 2050s period, the annual AETc ranges from $66 \mathrm{~mm}$ to $596 \mathrm{~mm}$, depicting the high values (over $500 \mathrm{~mm}$ ) in western, southern, and eastern sides of the study area. In the 
future years of 2050s, a larger area with high values of the annual AETc occupies the territory in comparison with the 1990s and 2020s. Figure A5 illustrates the spatial distribution of annual AETc in Carpathian Mountains area.
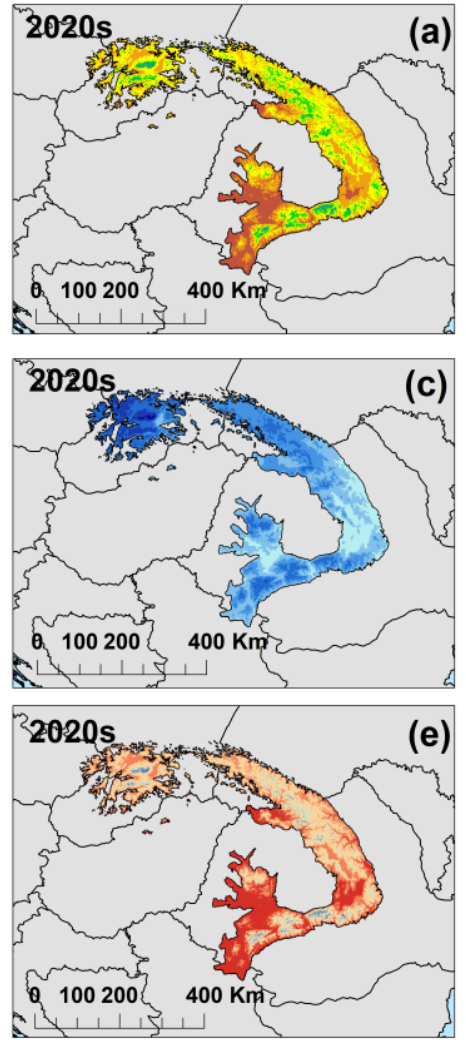

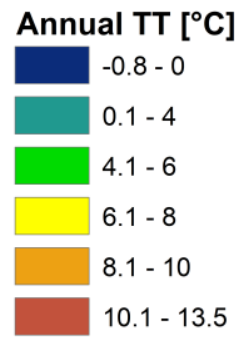

(c) Annual PP [mm]

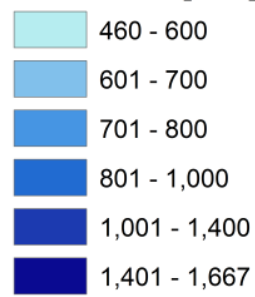

(e)
Annual ETO [mm]

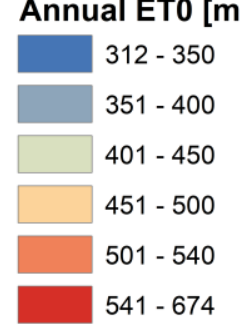

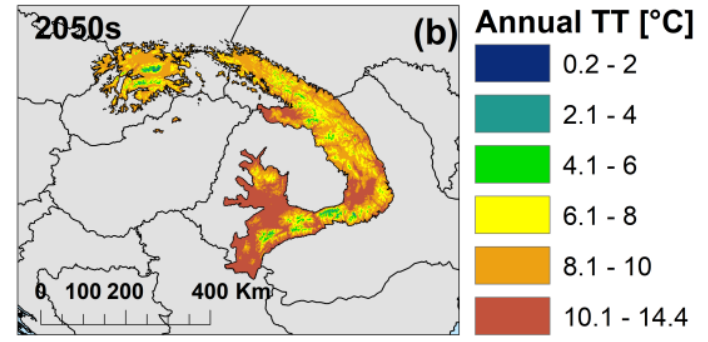

(d) Annual PP [mm]
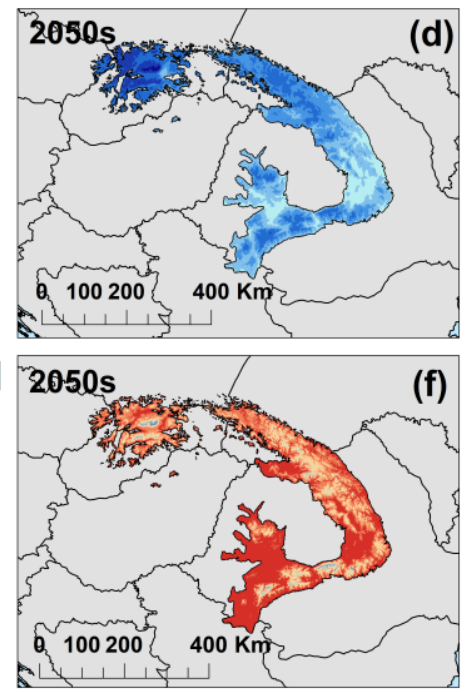

(f)

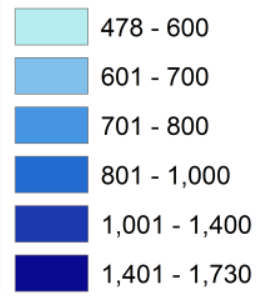

Annual ET0 [mm]

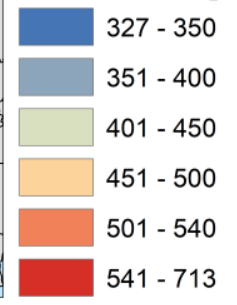

Figure 6. Models projections of temperature, precipitation, and ETO in the Carpathian Mountains region. (a) The average of mean annual air temperature between 2011 and 2040 (2020s). (b) The average of mean annual air temperature between 2041 and 2070 (2050s). (c) The average of mean annual precipitation between 2011 and 2040 (2020s). (d) The average of mean annual precipitation between 2041 and 2070 (2050s). (e) The average of annual ET0 between 2011 and 2040 (2020s). (f) The average of annual ETO between 2041 and 2070 (2050s)

Considering the annual AETc and precipitation patterns, the annual water availability was carried out for the 1990s, 2020s, and 2050s periods. In the Carpathian Mountains area, the water availability ranges during 1990s from $129 \mathrm{~mm}$ to $1635 \mathrm{~mm}$ (Fig. 6a), indicating the lower values (below $200 \mathrm{~mm}$ ) in the South of Apuseni Mountains, in the western sides of the Curvatures Carpathians, eastern side of the Eastern Carpathains. The high values (over $800 \mathrm{~mm}$ ) of the water availability spread in the Southern Carpathians and Western Carpathians, but also in the North of Eastern Carpathians. During the 2020s period, the water availability ranges from $66 \mathrm{~mm}$ to $1603 \mathrm{~mm}$ illustrating a large area with low water availability (below $200 \mathrm{~mm}$ ) in the Southern and Eastern Carpathians. The annual water availability ranges in the 2050s from $69 \mathrm{~mm}$ to $1663 \mathrm{~mm}$ depicting low values of water availability in the Apuseni Mountains, Southern and Eastern Carpathians. Figure 7 shows the water availability variation in the Carpathian Mountains area at spatial scale. 

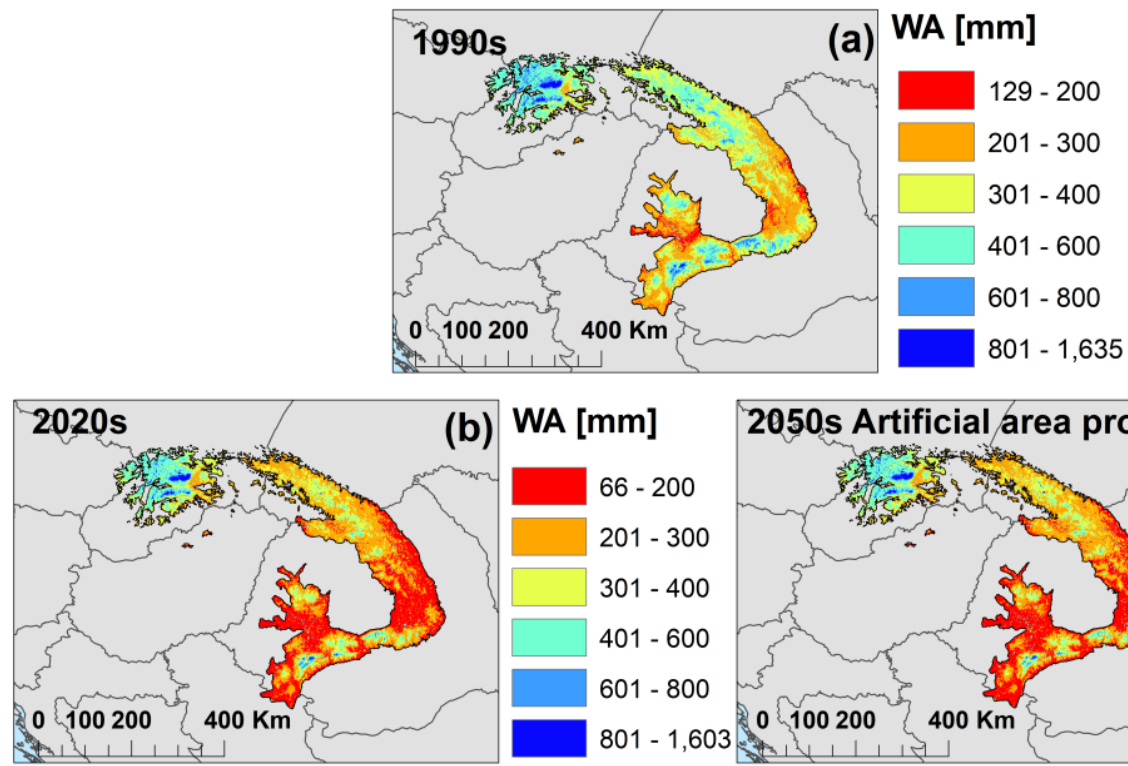

(b) WA [mm]
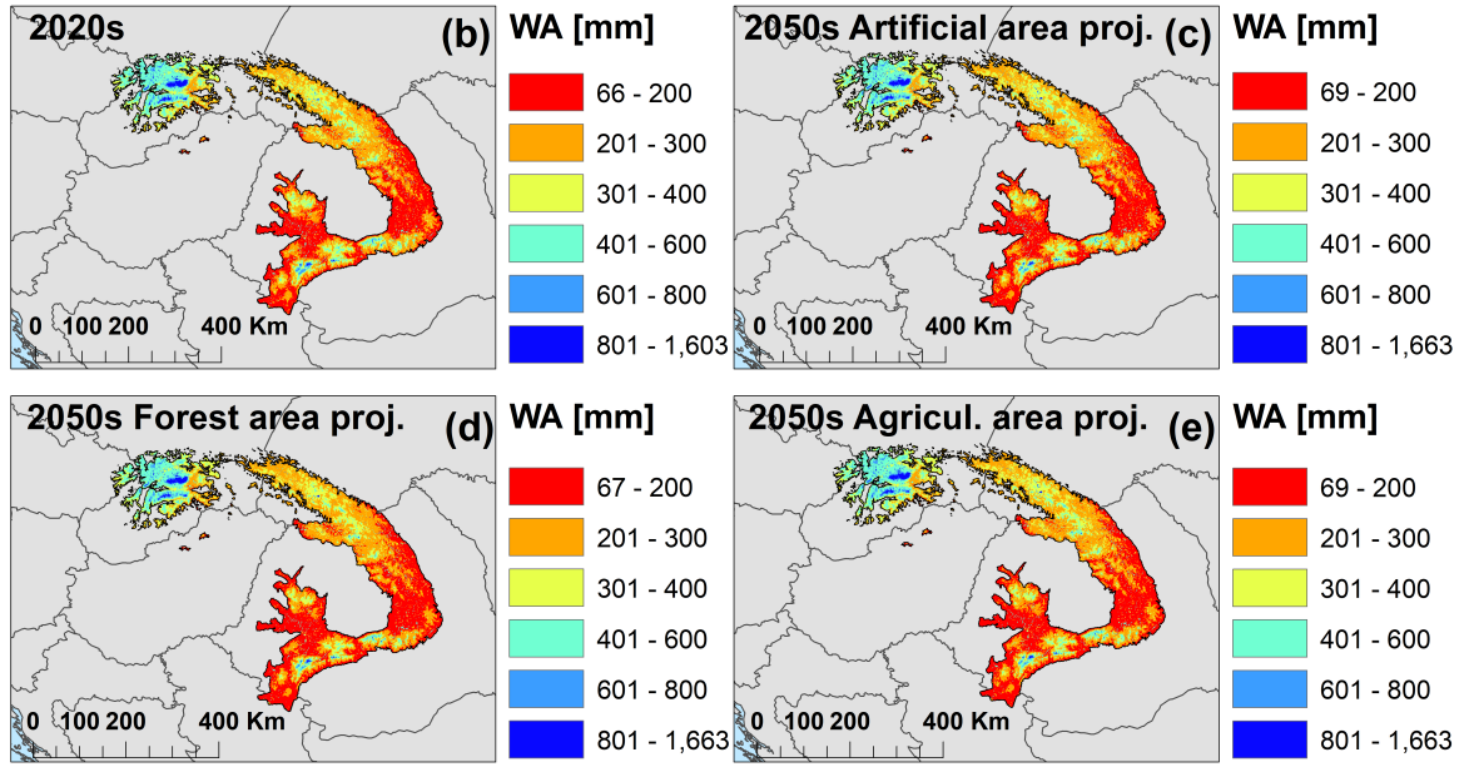

Figure 7. Spatial distribution of water availability (WA) in the Carpathian Mountains region. (a) WA related to the past period (1990s). (b) WA related to the present period (2020s). (c) WA related to the future period (2050s) artificial area projection. (d) WA related to the future period (2050s) forest area projection. (e) WA related to the future period (2050s) agricultural area projection

Groundwater vulnerability at spatial scale in the Carpathian Mountains area was calculated using spatial analysis by weights in the ArcGIS environment. A complex methodology was applied using climate models, geological data, DEM, and land cover of the study area. Figure $7 a$ depicts the groundwater vulnerability map of Carpathian Mountains area during 1990s. The groundwater vulnerability in the 1990s shows major part of the territory as low vulnerable at climate change and land cover. The very low class was depicted in the Western and Southern Carpathians only in the elevated areas (above $2000 \mathrm{~m}$ ). The high vulnerability areas were found in the Curvatures Carpathians and South of Apuseni Mountains. During the 2020s years the groundwater vulnerability map (Fig. 8b) indicates a large area of high vulnerability class, especially in the Curvatures Carpathians, while the very low vulnerability reduced at spatial scale. The future scenarios (Fig. $8 c-e$ ) show decreasing in area of very low vulnerability class and increase of the high vulnerability class. The forest projection indicate the maps of worst scenario with $2.41 \%$ from the total area with high vulnerability, followed by the artificial area projection (Table 5). 

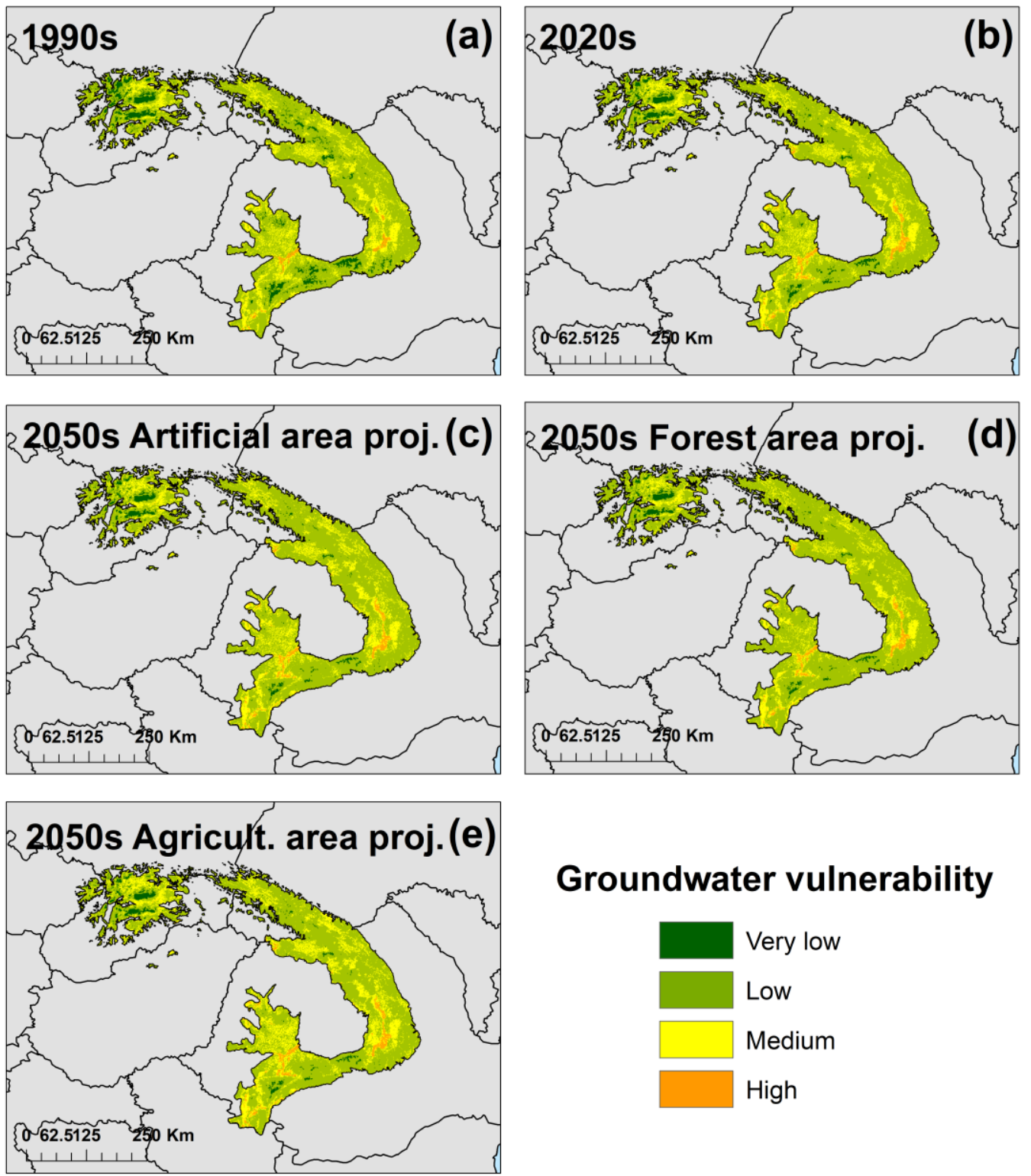

\section{Groundwater vulnerability}

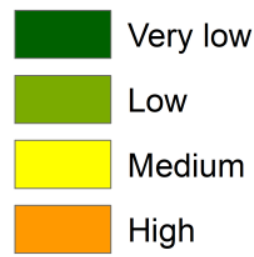

Figure 8. Groundwater vulnerability map of the Carpathian Mountains region. (a)

Groundwater vulnerability map related to the past period (1990s). (b) Groundwater vulnerability map related to the present period (2020s). (c) Groundwater vulnerability map related to the future period (2050s) artificial area projection. (d) Groundwater vulnerability map related to the future period (2050s) forest area projection. (e) Groundwater vulnerability map related to the future period (2050s) agricultural area projection

The main aim of this work was to calculate the groundwater vulnerability at spatial scale of Carpathian region area. The analysis of multi-layers data in ArcGIS was focused on the climate models and land cover projections. Under the climate change, the southern areas of Carpathians are negatively affected in terms of groundwater vulnerability increases. These modifications are related to the increase of territory with low water availability (below $200 \mathrm{~mm}$ ) for the 2020s and 2050s, in all scenarios. In this sense, the groundwater vulnerability increase from the quantitative point of view 
because the recharge of aquifers might a reduction. The quality of the groundwater was mainly controlled in our analysis by aquifers potential infiltration coefficient (PIC) (Fig. A2) and the pollution load index (PLI) (Fig. 5). As a first driver of groundwater quality, the higher PIC varies in the Carpathian Mountains region overlapping with the existing aquifers in limestones, sandstones, sandy, and gravels. These aquifers are defined as highly productive porous aquifers located mainly in the intermountain depressions. In these types of aquifers the hydraulic conductivity in relatively higher than in the aquifers formed by schists and gneisses or plutonic rocks. Secondly, the PLI factor follow the land cover distribution (Fig. A3). Thus, the artificial areas and agricultural lands influence the increases of groundwater vulnerability, while the forest and grass form the ecosystems, which provide an advantageous media for groundwater quality. For this reason, the low vulnerability extends on larger area (around 77.73\%) in the forest projection model.

Table 5. Percentage area of groundwater vulnerability calculated in Carpathian Mountains area

\begin{tabular}{c|c|c|c|c|c}
\hline $\begin{array}{c}\text { Vulnerability } \\
\text { classes }\end{array}$ & $\begin{array}{c}\text { GW } \\
\text { vulnerability } \\
\text { 1990s } \\
\text { (area \%) }\end{array}$ & $\begin{array}{c}\text { GW } \\
\text { vulnerability } \\
\text { 2020s } \\
\text { (area \%) }\end{array}$ & $\begin{array}{c}\text { GW vulnerability } \\
\text { 2050s, artificial } \\
\text { projection } \\
\text { (area \%) }\end{array}$ & $\begin{array}{c}\text { GW vulnerability } \\
\text { 2050s, forest } \\
\text { projection } \\
\text { (area \%) }\end{array}$ & $\begin{array}{c}\text { GW vulnerability } \\
\text { 2050s, agriculture } \\
\text { projection } \\
\text { (area \%) }\end{array}$ \\
\hline Very low & 6.19 & 3.50 & 2.75 & 2.49 & 2.67 \\
Low & 70.45 & 71.73 & 72.29 & 77.73 & 68.66 \\
Medium & 22.16 & 22.64 & 22.83 & 17.87 & 26.25 \\
High & 1.19 & 2.13 & 2.13 & 1.91 & 2.41 \\
\hline
\end{tabular}

The methodology of groundwater calculation and land cover projection applied in this survey is close to the procedure followed by Nistor et al. (2015). They used the appropriate data to determine the groundwater vulnerability on a district from Apuseni Mountains, in Romanian Carpathians. Here, we extrapolated the methodology to entire area of Carpathians Mountains using spatial analysis in ArcGIS. With few changes regarding the utilization of high-resolution climate models and geology implication, our results indicate appropriate pattern of groundwater vulnerability with the studies carried out by Čenčur Curk et al. (2014), Nistor et al. (2015). The limitations of this study may be improved using in-situ monitoring of spring's groundwater to observe the climate change effects on seasonal periods. In this study, we have focused on long-term period analysis, so the runoff and water availability variables on short-term period were neglected. Using additional methods, such as VESPA index (Galleani et al., 2011), ) or spring variability in base of hydrographs, the groundwater vulnerability could be performed in specific locations and further to create various models at spatial scale. At this level, GIS techniques were the best solutions in sense of long-term period, land cover projections, and layer analysis.

\section{Conclusions}

Spatial analysis by weights in ArcGIS environment contributed to determine the groundwater vulnerability in the Carpathian Mountains area. A complex methodology including the climate models in three periods, aquifers and geology, morphometric 
terrain data, and the dynamic land use layers indicates a quarter part of the Carpathian Mountains area territory suffers high and very high groundwater vulnerability under climate change. Moreover, the future scenarios highlight almost a third part of the region in the high and very high vulnerability class. These results evidence that the territory of the Carpathian Mountains area is faced with the actual global threats that may occur also at regional scale. These problems are mainly related to both a reduction of precipitation amount and an increase in the mean air temperature. These findings can help the policymakers and the administrative staff of the region to take the counterbalance measures against the natural changes that are expected during the $21 \mathrm{st}$ century. The maps carried out in this study may represent strategic tools for the landscaping and delineating the areas with more restrictive actions.

We presented a long-term analysis which is based on spatial data and empirical formulas. Considering the complexity of the data used here, the errors may be neglected for the long period. However, the methodology was applied for other study cases from Europe and we assume that our results are valid. To be more accurate, the future work could be conducted at site scale to assess the groundwater vulnerability in situ (i.e. springs, check quality of groundwater in wells). The groundwater quality in the agricultural areas and different flow models of groundwater may improve the results at local scale.

Acknowledgements. The authors would like to thank Andreas Hamann from Alberta University for the climate models data and support during the revision process.

\section{REFERENCES}

[1] Aguilera, H., Murillo, J. M. (2009): The effect of possible climate change on natural groundwater recharge based on a simple model: a study of four karstic aquifers in SE Spain. - Environmental Geology 57(5): 963-974.

[2] Allen, R. G., Pereira, L. S., Raes, D., Smith, M. (1998): Crop evapotranspiration: guidelines for computing crop water requirements. - FAO Irrigation and Drainage Paper 56 , Rome.

[3] BGR and UNESCO (2013): International Hydrogeological Map of Europe (IHME1500) $1: 1,500,000$. - International Association of Hydrogeologists. http://www.bgr.bund.de/ihme1500/.

[4] Budyko, M. I. (1974): Climate and Life. - Academic Press, New York.

[5] Čenčur Curk, B., Cheval, S., Vrhovnik, P., Verbovšek, T., Herrnegger, M., Nachtnebel, H. P., Marjanović, P., Siegel, H., Gerhardt, E., Hochbichler, E., Koeck, R., Kuschnig, G., Senoner, T., Wesemann, J., Hochleitner, M., Žvab Rožič, P., Brenčič, M., Zupančič, N., Bračič Železnik, B., Perger, L., Tahy, A., Tornay, E. B., Simonffy, Z., Bogardi, I., Crăciunescu, A., Bilea, I. C., Vică, P., Onuţu, I., Panaitescu, C., Constandache, C., Bilanici, A., Dumitrescu, A., Baciu, M., Breza, T., Marin, L., Draghici, C., Stoica, C., Bobeva, A., Trichkov, L., Pandeva, D., Spiridonov, V., Ilcheva, I., Nikolova, K., Balabanova, S., Soupilas, A., Thomas, S., Zambetoglou, K., Papatolios, K., Michailidis, S., Michalopoloy, C., Vafeiadis, M., Marcaccio, M., Errigo, D., Ferri, D., Zinoni, F., Corsini, A., Ronchetti, F., Nistor, M. M., Borgatti, L., Cervi, F., Petronici, F., Dimkić, D., Matić, B., Pejović, D., Lukić, V., Stefanović, M., Durić, D., Marjanović, M., Milovanović, M., Boreli-Zdravković, D., Mitrović, G., Milenković, N., Stevanović, Z., Milanović, S. (2014): CC-WARE Mitigating Vulnerability of Water Resources under 
Climate Change. WP3 - Vulnerability of Water Resources in SEE. - Report Version 5. http://www.ccware.eu/output-documentation/output-wp3.html.

[6] Cheval, S., Dumitrescu, A., Barsan, M. V. (2017): Variability of the aridity in the SouthEastern Europe over 1961-2050. - Catena 151: 74-86.

[7] Civita, M. (2005): Idrogeologia applicata ed ambientale. - CEA, Milano, Italy (in Italian).

[8] Daly, C. (2006): Guidelines for assessing the suitability of spatial climate data sets. - Int. J. Climatol. 26: 707-721.

[9] Daly, D., Dassargues, A., Drew, D., Dunne, S., Goldscheider, N., Neale, S., Popescu, I. C., Zwahlen, F. (2002): Main concepts of the "European approach" to karstgroundwatervulnerability assessment and mapping. - Hydrogeology Journal 10: 340-345.

[10] Dezsi, Şt., Mîndrescu, M., Petrea, D., Rai, K. P., Hamann, A., Nistor, M. M. (2018): High-resolution projections of evapotranspiration and water availability for Europe under climate change. - International Journal of Climatology 38(10): 3832-3841. https://doi.org/10.1002/joc.5537.

[11] Dixon, B. (2005): Groundwater vulnerability mapping: A GIS and fuzzy rule based integrated tool. - Applied Geography 25: 327-347.

[12] Galleani, L., Vigna, B., Banzato, C., Lo Russo, S. (2011): Validation of a vulnerability estimator for spring protection areas: The VESPA index. - Journal of Hydrology 396: 233-245.

[13] Grimmond, C. S. B., Oke, T. R. (1999): Evapotranspiration rates in urban areas. Impacts of urban growth on surface water and groundwater quality. - Proceedings of IUGG 99 Symposium HSS. Birmingham, July J999. IAHS. Publ. no. 259: 235-243.

[14] Haeberli, W. R., Frauenfelder, R., Hoelzle, M., Maisch, M. (1999): On rates and acceleration trends of global glacier mass changes. - Physical Geography 81A: 585-595.

[15] Hamann, A., Wang, T. L. (2005): Models of climatic normals for genecology and climate change studies in British Columbia. - Agricultural and Forest Meteorology 128: 211221.

[16] Hamann, A., Wang, T., Spittlehouse, D. L., Murdock, T. Q. (2013): A comprehensive, high-resolution database of historical and projected climate surfaces for western North America. - Bulletin of the American Meteorological Society 94: 1307-1309.

[17] IPCC (2001): Climate Change 2001: The Scientific Basis. - In: Houghton J. T., Ding Y., Griggs, D. J., Noguer, M., van der Linden, P. J., Dai, X., Maskell, K., Johnson, C. A. (eds.) Contribution of Working Group I to the Third Assessment Report of the Intergovernmental Panel on Climate Change. Cambridge University Press, Cambridge, United Kingdom and New York, NY, USA.

[18] IPCC (2013): Summary for Policymakers. - In: Stocker, T. F., Qin, D., Plattner, G.-K., Tignor, M., Allen, S. K., Boschung, J., Nauels, A., Xia, Y., Bex, V., Midgley, P. M. (eds.) Climate Change 2013: The Physical Science Basis. Contribution of Working Group I to the Fifth Assessment Report of the Intergovernmental Panel on Climate Change. Cambridge University Press, Cambridge, United Kingdom and New York, USA.

[19] Jiménez Cisneros, B. E., Oki, T., Arnell, N. W., Benito, G., Cogley, J. G., Döll, P., Jiang, T., Mwakalila, S. S. (2014): Freshwater resources. - In: Field, C. B., Barros, V. R., Dokken, D. J., Mach, K. J., Mastrandrea, M. D., Bilir, T. E., Chatterjee, M., Ebi, K. L., Estrada, Y. O., Genova, R. C., Girma, B., Kissel, E. S., Levy, A. N., MacCracken, S., Mastrandrea, P. R., White, L. L. (eds.) Climate Change 2014: Impacts, Adaptation, and Vulnerability. Part A: Global and Sectoral Aspects. Contribution of Working Group II to the Fifth Assessment Report of the Intergovernmental Panel on Climate Change. Cambridge University Press, Cambridge, United Kingdom and New York, NY, USA, pp. 229-269.

[20] Kløve, B., Ala-Aho, P., Bertrand, G., Gurdak, J. J., Kupfersberger, H., Kværner, J., Muotka, T., Mykrä, H., Preda, E., Rossi, P., Bertacchi Uvo, C., Velasco, E., PulidoVelazquez, M. (2014): Climate change impacts on groundwater and dependent ecosystems. - Journal of Hydrology 518: 250-266. 
[21] Knutti, R., Masson, D., Gettelman, A. (2013): Climate model genealogy: generation CMIP5 and how we got there. - Geophysical Research Letters 40: 1194-1199.

[22] Kottek, M., Grieser, J., Beck, C., Rudolf, B., Rubel, F. (2006): World Map of the Köppen-Geiger climate classification updated. - Meteorologische Zeitschrift 15(3): 259263.

[23] Mbogga, M. S., Hamann, A., Wang, T. (2009): Historical and projected climate data for natural resource management in western Canada. - Agricultural and Forest Meteorology 149: 881-890.

[24] Mitchell, T. D., Jones, P. D. (2005): An improved method of constructing a database of monthly climate observations and associated high-resolution grids. - International Journal of Climatology 25: 693-712.

[25] New, M., Hulme, M., Jones, P. (1998): Representing Twentieth-Century Space-Time Climate Variability. Part I: Development of a 1961-90 Mean Monthly Terrestrial Climatology. - Journal of Climate 12: 829-856.

[26] Nistor, M. M. (2018a): Climate change effect on groundwater resources in South East Europe during 21st century. - Quaternary International 2018. https://doi.org/10.1016/j.quaint.2018.05.019.

[27] Nistor, M. M. (2018b): Seasonal and annual crop evapotranspiration in Europe over 2011-2070. - Applied Ecology and Environmental Research 16(3): 2149-2168.

[28] Nistor, M. M., Mîndrescu, M. (2017): Climate change effect on groundwater resources in Emilia-Romagna region: An improved assessment through NISTOR-CEGW method. Quaternary International. https://doi.org/10.1016/j.quaint.2017.11.018.

[29] Nistor, M. M., Porumb-Ghiurco, G. C. (2015): How to compute the land cover evapotranspiration at regional scale? A spatial approach of Emilia-Romagna region. GEOREVIEW Scientific Annals of Ştefan cel Mare University of Suceava Geography Series 25(1): 38-54.

[30] Nistor, M. M., Dezsi Șt., Cheval, S. (2015): Vulnerability of groundwater under climate change and land cover: a new spatial assessment method applied on Beliş district (Western Carpathians, Romania). - Environmental Engineering and Management Journal 14(12): 2959-2971.

[31] Nistor, M. M., Dezsi, St., Cheval, S., Baciu, M. (2016): Climate change effects on groundwater resources: a new assessment method through climate indices and effective precipitation in Beliş district, Western Carpathians. - Meteorological Applications 23: 554-561.

[32] Nistor, M. M., Man, T. C., Benzaghta, M. A., Nedumpallile, Vasu, N., Dezsi, Şt., Kizza, R. (2018): Land cover and temperature implications for the seasonal evapotranspiration in Europe. - Geographia Technica 13(1): 85-108.

[33] Ohgaito, R., Sueyoshi, T., Abe-Ouchi, A., Hajima, T., Watanabe1, S., Kim, H.-J., Yamamoto, A., Kawamiya, M. (2013): Can an Earth System Model simulate better climate change at mid-Holocene than an AOGCM? A comparison study of MIROC-ESM and MIROC3. - Clim. Past. 9: 1519-1542.

[34] Scherrer, S. C. (2011): Present-day interannual variability of surface climate in CMIP3 models and its relation to future warming. - International Journal of Climatology 31: $1518-1529$.

[35] Shaver, G. R., Canadell, J., Chapin III, F. S., Gurevitch, J., Harte, J., Henry, G., et al. (2000): Global warming and terrestrial ecosystems: a conceptual framework for analysis. - BioScience 50(10): 871-882.

[36] Stavig, L., Collins, L., Hager, C., Herring, M., Brown, E., Locklar, E. (2005): The effects of climate change on Cordova, Alaska on the Prince William Sound. Alaska Tsunami Papers. - $\quad$ The National Ocean Sciences Bowl. https://seagrant.uaf.edu/nosb/papers/2005/cordova-nurds.html (accessed 23 April 2014). 
[37] Stempvoort, D. V., Ewert, L., Wassenaar, L. (1993): Aquifers vulnerability index: a GIScompatible method for groundwater vulnerability mapping. - Canadian Water Resources Journal/Revue canadienne des ressources hydriques 18: 25-37.

[38] Stocks, B. J., Fosberg, M. A., Lynham, T. J., Mearns, L., Wotton, B. M., Yang, Q., et al. (1998): Climate change and forest fire potential in Russian and Canadian boreal forests. Clim. Change 38: 1-13.

[39] The Canadian Centre for Climate Modelling and Analysis. (2014): The first generation coupled global climate model publishing web. - http://www.ec.gc.ca/ccmacccma/default.asp?lang=En\&n=540909E4-1 (accessed 20 March 2015).

[40] Thornthwaite, C. W. (1948): An approach toward a rational classification of climate. Geogr. Rev. 38: 55-94.

[41] Wang, T., Hamann, A., Spittlehouse, D. L., Carroll, C. (2016): Locally downscaled and spatially customizable climate data for historical and future periods for North America. PLoS One 11: e0156720.

[42] Watanabe, S., Hajima, T., Sudo, K., Nagashima, T., Takemura, T., Okajima, H., Nozawa, T., Kawase, H., Abe, M., Yokohata, T., Ise, T., Sato, H., Kato, E., Takata, K., Emori, S., Kawamiya, M. (2011): MIROC-ESM 2010: model description and basic results of CMIP5-20c3m experiments. - Geosci. Model Dev. 4: 845-872.

[43] Zhao, L., Xia, J., Xu, C., Wang, Z., Sobkowiak, L., Long, C. (2013): Evapotranspiration estimation methods in hydrological models. - Journal of Geographical Sciences 23(2): 359-369. 


\section{APPENDIX}

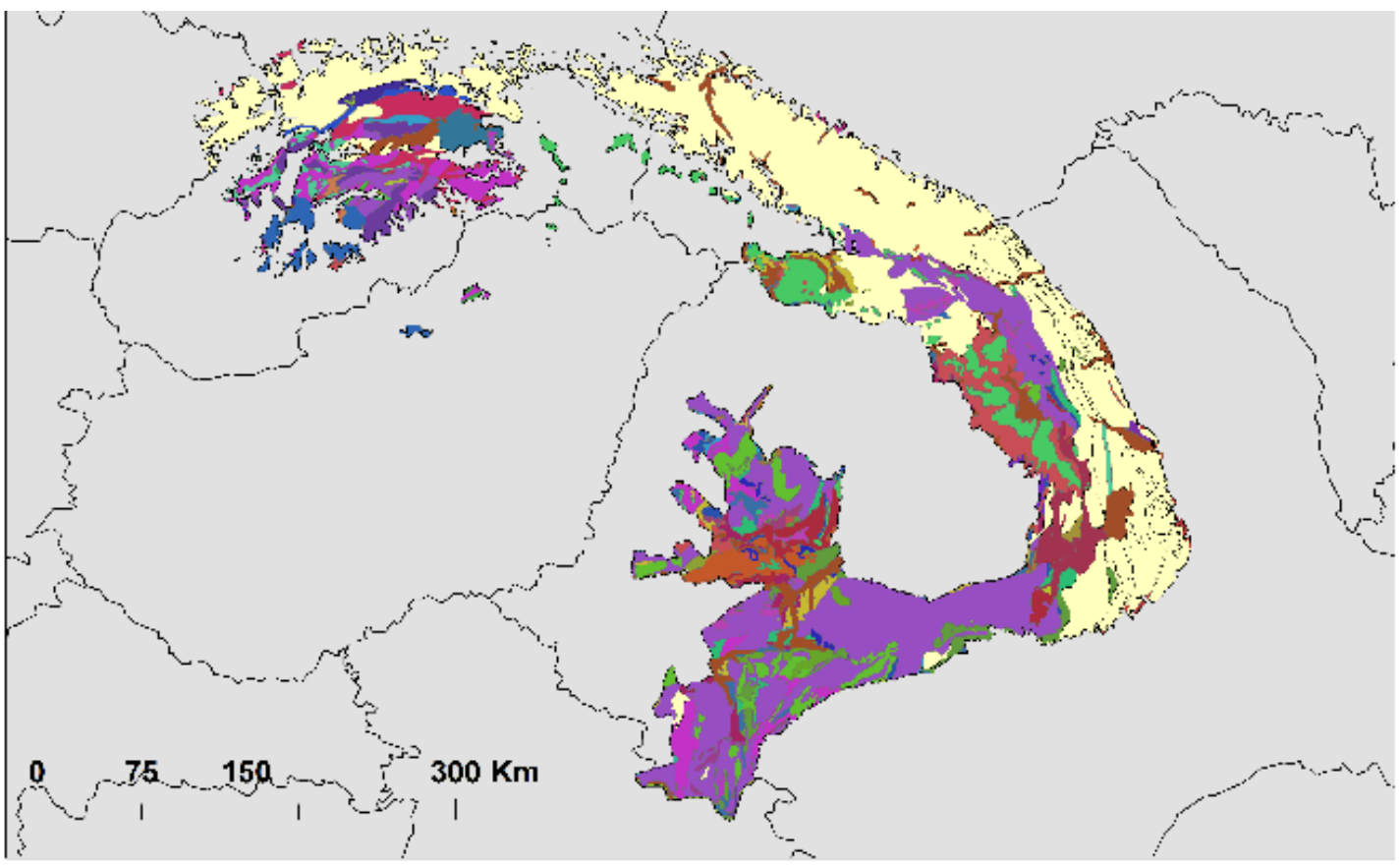

\section{Geological formations}

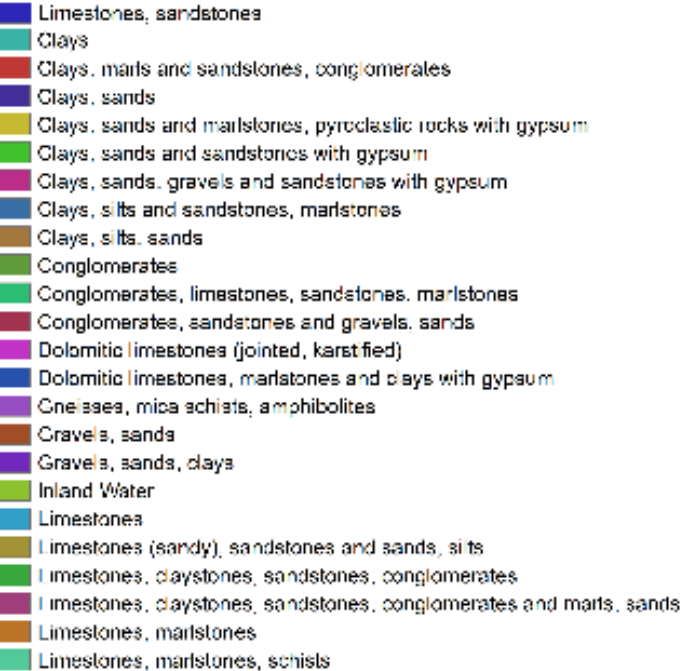

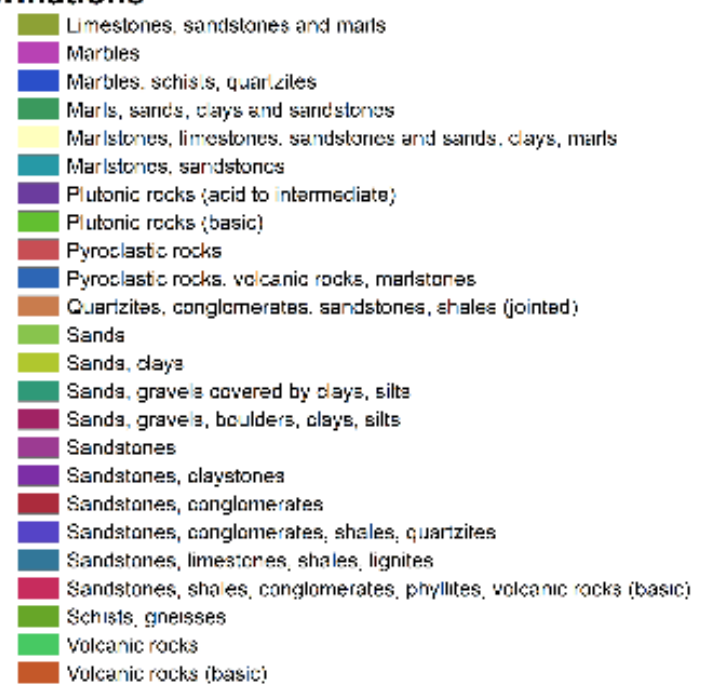

Figure A1. Geological formations of the Carpathian Mountains region 


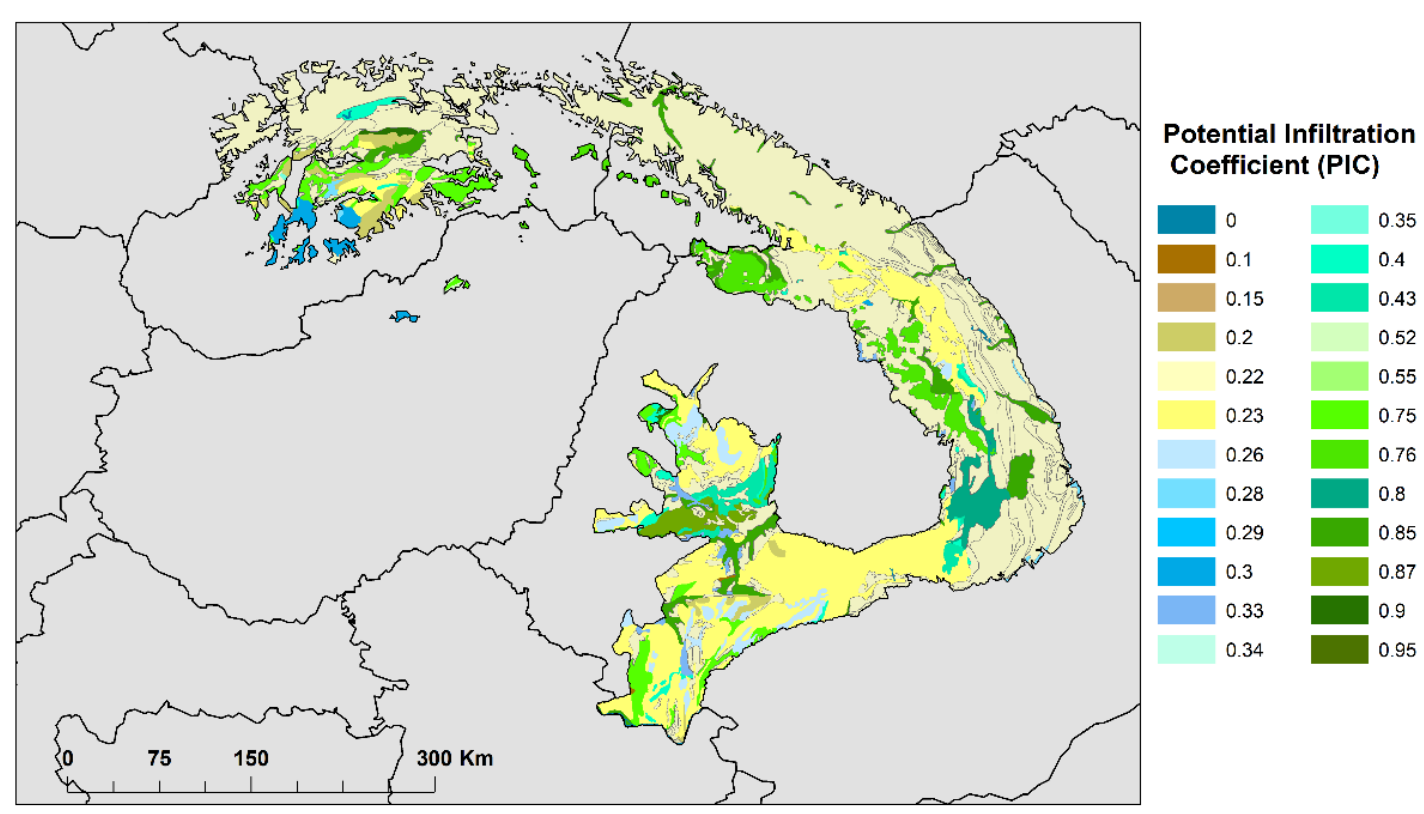

Remark: Potential Infiltration Coefficient (\%) for the aquifers typology was asigned accordingly with the specific literature.

Figure A2. Potential infiltration coefficient assigned to each type of aquifer in the Carpathian Mountains region
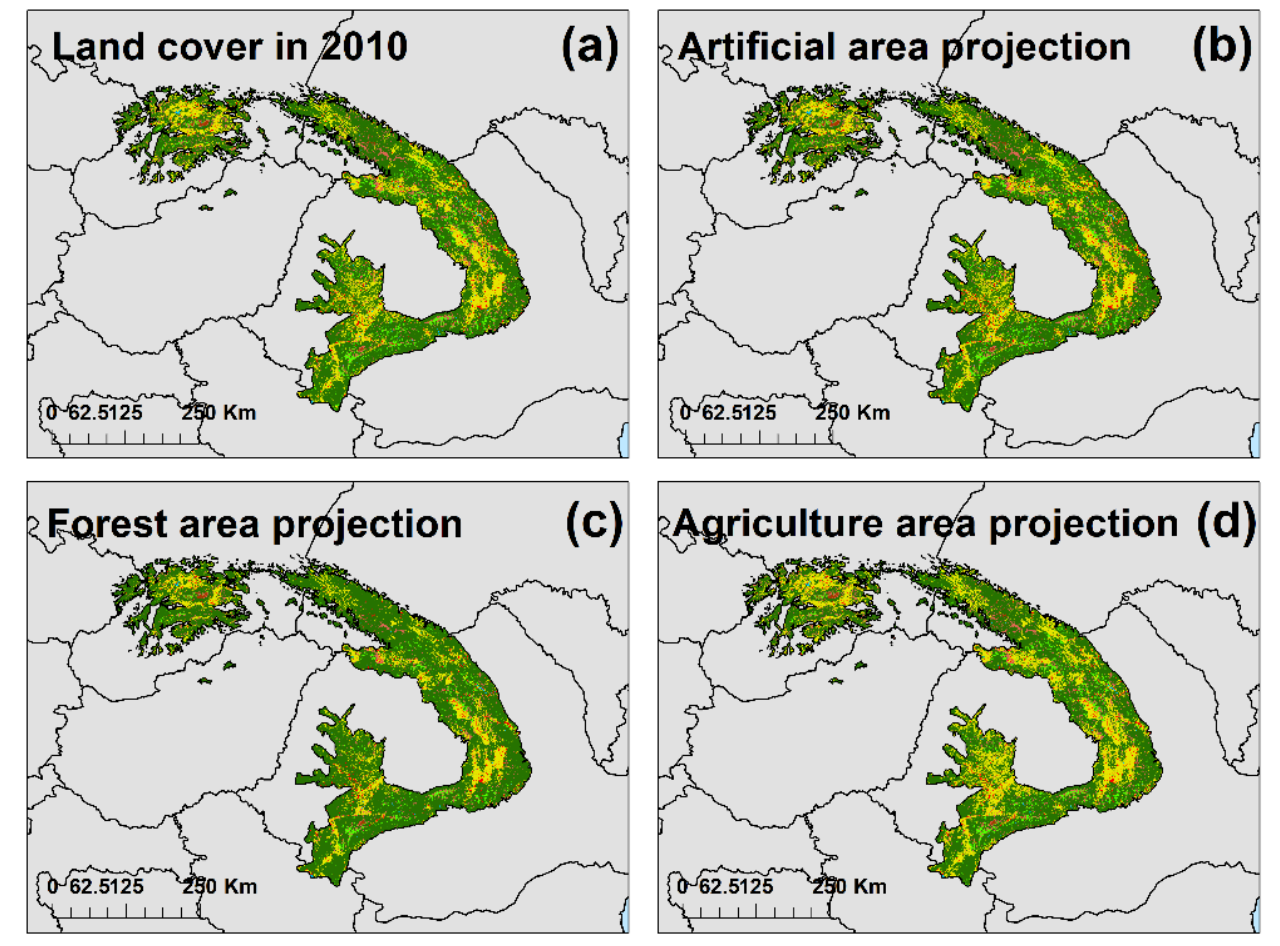

\section{Land cover}
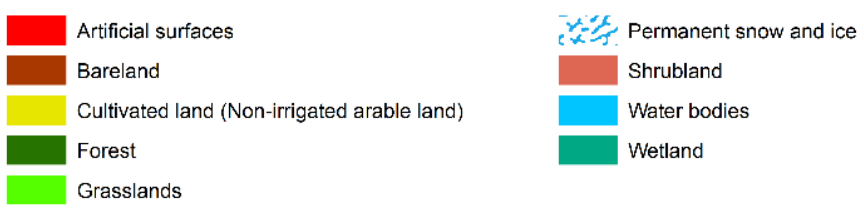

Figure A3. Land cover of the Carpathian Mountains region in 2010 and future projections 

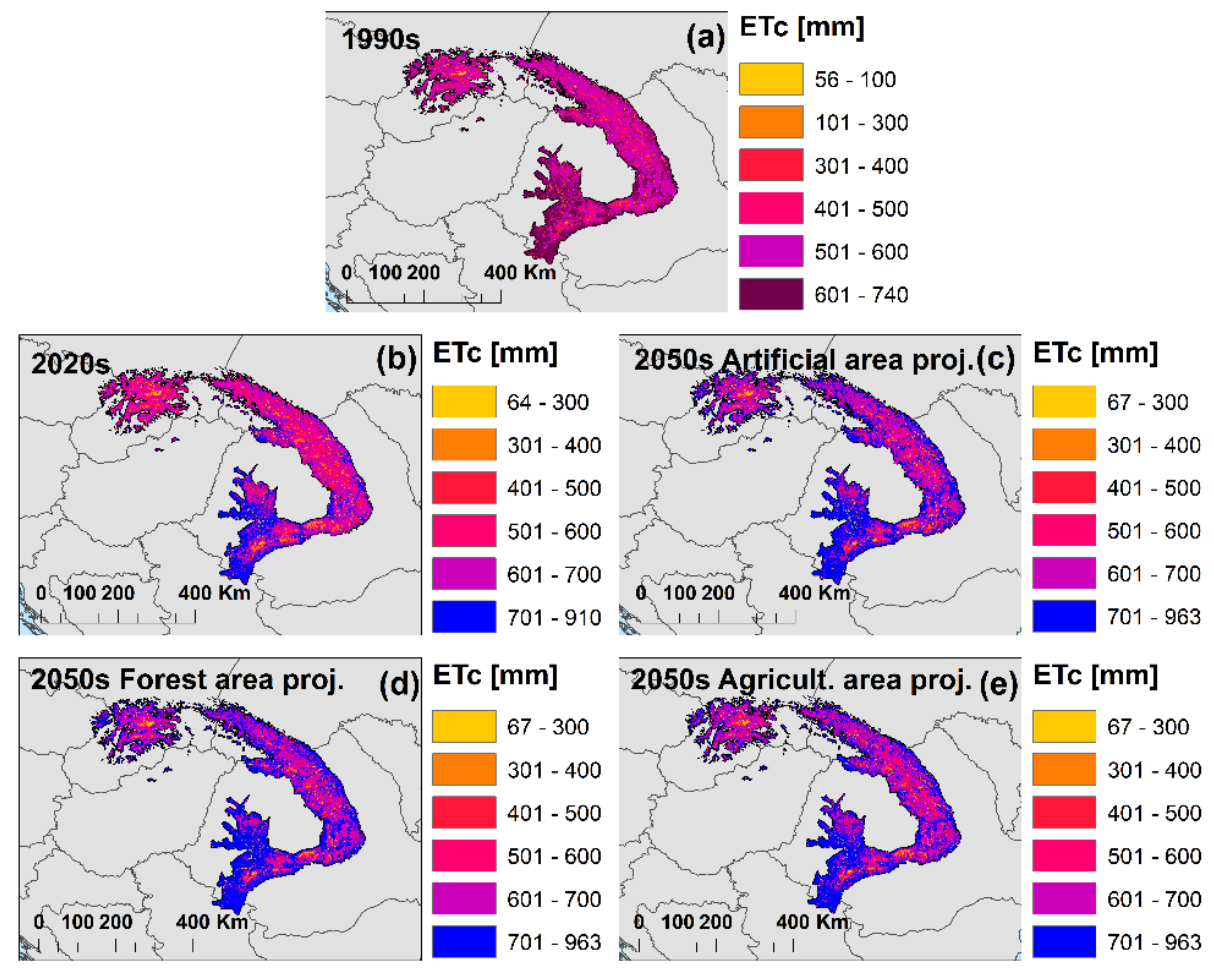

Figure A4. Spatial distribution of annual crop evapotranspiration (ETc) in the Carpathian Mountains region and future projection under land cover and climate models
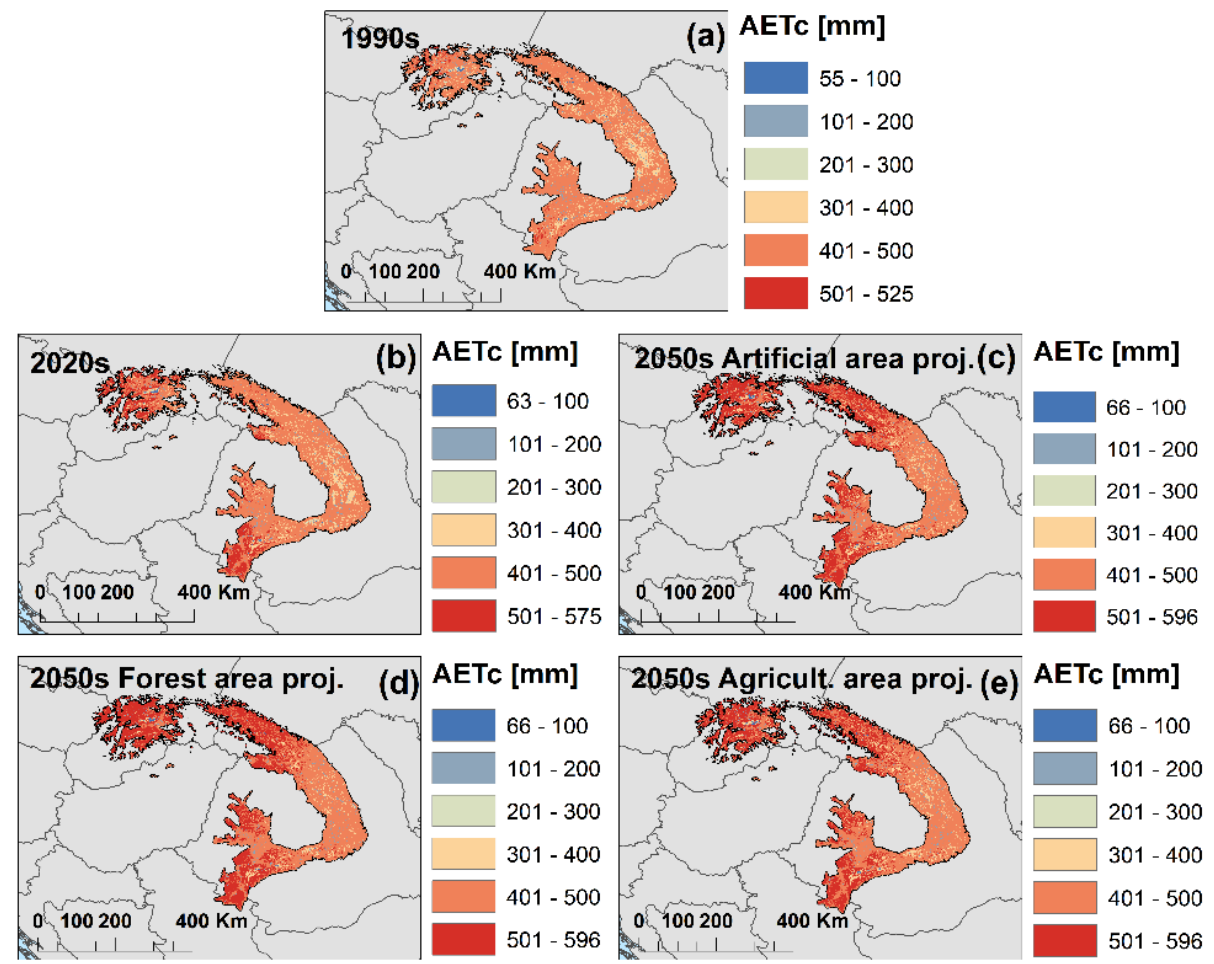

Figure A5. Spatial distribution of annual actual crop evapotranspiration (AETc) in the Carpathian Mountains region and future projection under land cover and climate models 